\title{
Utilizing copper-mediated deprotection of selenazolidine for cyclic peptides
}

\section{synthesis}

\section{Zhenguang Zhao ${ }^{1}$ and Norman Metanis, ${ }^{1, *}$}

1. The Institute of Chemistry, The Hebrew University of Jerusalem, Edmond J. Safra Campus, Givat Ram, Jerusalem 91904, Israel

\begin{abstract}
Selenazoliline (Sez) was originally developed as a masking form of selenocysteine (Sec) for the chemical synthesis of challenging proteins. Here we utilize Sez and our recent reported copper(II)-mediated deprotection for the synthesis of cyclic peptides. This approach allows deprotection, cyclization and deselenization in one-pot, providing several different cyclic peptides in good yields. In addition, the Sec can also be retained, which enhance the oxidative folding of disulfide-rich cyclic proteins, such as the case of Kalata S.
\end{abstract}

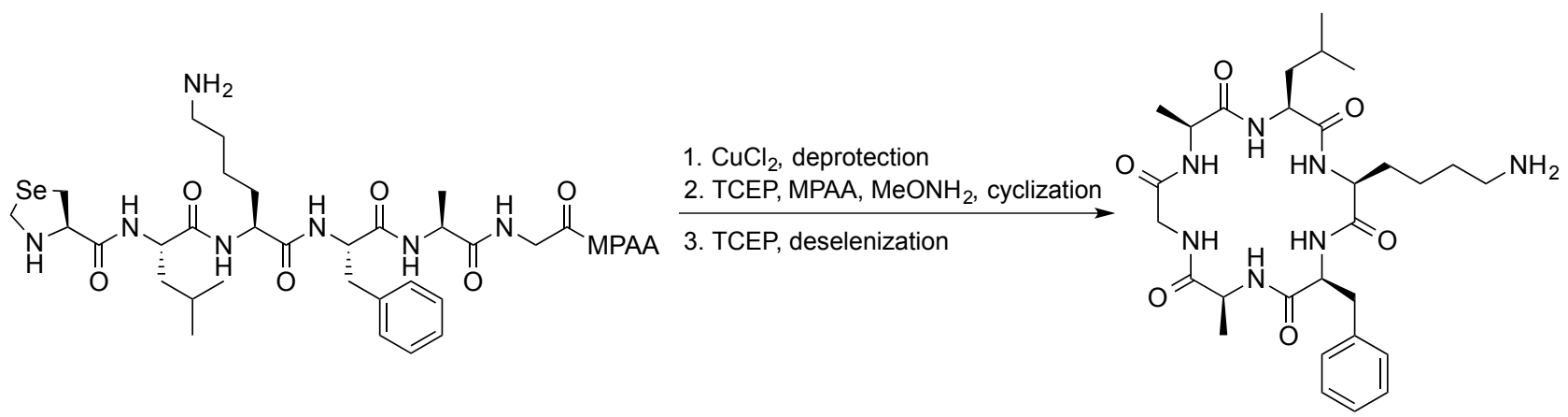


Cyclic peptides and proteins provide an attractive scaffold for developing complex, biologically active molecules due to their constrained conformation and unique structures. ${ }^{1-7}$ In addition to their extensive distribution in nature, ${ }^{2,8-11}$ cyclic peptides are promising drug candidates for a wide range of diseases. ${ }^{12-14}$ Compared to their linear counterparts, cyclic peptides often exhibit enhanced stability, increased efficiency and bioavailability. ${ }^{15,16}$ For the above reasons, cyclic peptides are becoming attractive synthetic targets for chemists and chemical biologists.

One strategy for preparing cyclic peptides is the lactamization of protected linear peptides in organic solvents after cleavage from solid support. ${ }^{17-20}$ A major limitation of this strategy is the use of coupling reagents to activate the acylating moiety, which in turn are known to cause epimerization at the peptide C-terminal residue. ${ }^{21}$ Further, the cyclization reaction must be conducted at high dilution to minimize polymerization side-reactions. Furthermore, side-chain protection is necessary, which decreases peptide solubility as its size increases. To overcome these challenges, a variety of approaches to synthesize cyclic peptides from linear unprotected peptide precursors have been developed. ${ }^{20,} 22-30$ Native chemical ligation (NCL), ${ }^{31}$ which allows chemoselective intramolecular cyclization of $\mathrm{C}$-terminal thioester and $\mathrm{N}$-terminal cysteine to form unprotected cyclic peptide $23,25,32$ is perhaps the most used and effective approach. This method exhibits several advantages, including limited polymerization side-reactions, virtually no epimerization, and efficient reactions on unprotected peptides in aqueous media.

Possessing properties similar to Cys, selenocysteine (Sec, U)-mediated NCL (Sec-NCL) was developed for the synthesis of seleno-proteins. ${ }^{33-41}$ Later, its use was expanded to many wild-type proteins without Sec upon the discovery that deselenization can be performed chemoselectively, without affecting unprotected Cys residues in the protein sequence. ${ }^{37-47}$ The synthesis of cyclic peptides by Sec-NCL has been developed using Fmoc-Sec(Mob)-OH. ${ }^{36,48}$ Yet, Mob deprotection can be challenging under standard cleavage conditions, ${ }^{49}$ and requires the addition of 2,2'-dithiobis(5-nitropyridine) (DTNP), ${ }^{50}$ in which a large excess of thiols (e.g. DTT) must be added to remove the 5-nitropyridine-2-thiol (5-Npys) group from Sec. ${ }^{51}$ Although using ascorbate to reduce the selenosulfide was reported, ${ }^{51,52}$ the ascorbate will inhibit the deselenization reaction, ${ }^{39,44}$ which make one-pot chemical synthesis of cyclic peptides challenging. Selenazolidine $(\mathrm{Sez})^{39,53,54}$ was developed as a protected form of Sec, which has been particularly useful for the synthesis of middle segment peptides in multi-NCL reactions for proteins with non-strategically positioned Cys 
residues. $^{39-41,45,55}$

Similar to thiazolidine (Thz), ${ }^{56} \mathrm{Sez}$ deprotection is usually implemented by $\mathrm{MeONH}_{2} \cdot{ }^{39}$ Yet, we sought on utilizing Sez in the synthesis of cyclic peptides using our newly developed $\mathrm{Cu}$ (II)-mediated Sez-deprotection approach, followed by intramolecular NCL cyclization and final deselenization step. Thus, peptide 1, Sez-LKFAG-COSR, was prepared as a model peptide containing N-terminal Sez and a C-terminal thioester. $\mathrm{MeONH}_{2}$ was tested for Sez deprotection in $\mathbf{1}$ followed by $\mathrm{NCL} /$ cyclization. However, $\mathrm{MeONH}_{2}$ reacted with thioester to form the methoxyamide bond (Intermediate 2) simultaneously, which stopped the further cyclization of 1 (Scheme 1), and instead of cyclic peptide 1', peptide 2 was the major product (Scheme 1, Scheme S1 and Figure S1 in SI). This result is consistent with previous work by other groups. ${ }^{56-59}$ To overcome this limitation, we decided to use our recently reported $\mathrm{Cu}(\mathrm{II})$-mediated deprotection of Sez for the synthesis of cyclic peptides and proteins ${ }^{55}$ in one-pot deprotection and cyclization followed by deselenization without additional HPLC purifications.

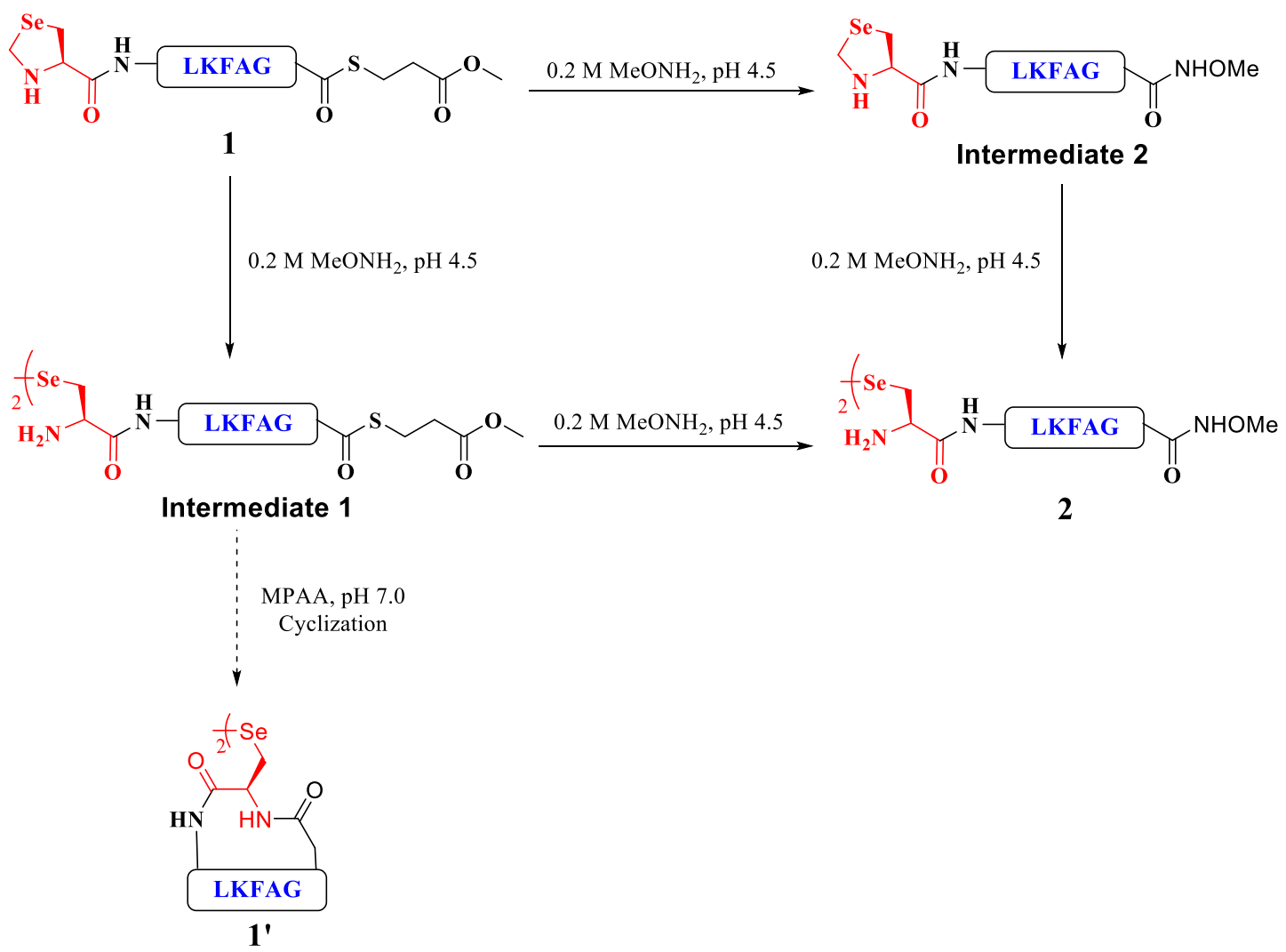

Scheme 1. $\mathrm{MeONH}_{2}$ deprotects Sez and simultaneously reacts with the thioester to give $\mathbf{2}$. 
To develop an efficient one-pot deprotection, cyclization and deselenization method, we explored the performance of a Sez-peptide-arylthioester (Sez-peptide-MPAA) ${ }^{60}$ (Figure 1a). We reasoned that the cyclization step should proceed efficiently with the highly activated arylthioester, with no other MPAA additives in solution.

To test this approach, peptide 3a (Sez-LKFAG-MPAA) was synthesized using an acylurea thioester precursor. ${ }^{61,62}$ After deprotection of $\mathbf{3 a}$ with $\mathrm{CuCl}_{2}\left(0.2 \mathrm{M} \mathrm{PB}, 6 \mathrm{M} \mathrm{Gn} \cdot \mathrm{HCl}, 1.5\right.$ equiv $\mathrm{CuCl}_{2}, \mathrm{pH} 6$, $\left.25^{\circ} \mathrm{C}\right)^{55}$, TCEP and ascorbate were added to the reaction, and $\mathrm{pH}$ was adjusted to $6.5-7$. In total, the deprotection and cyclization were completed in $1 \mathrm{~h}$ (Figure 1b). Yet, the subsequent deselenization was greatly inhibited due to the presence of MPAA ${ }^{37}$ and ascorbate. ${ }^{37,39,44}$ We tested if a PD-10 desalting column could be used to remove those additives. ${ }^{63}$ However, deselenization reaction was still slower than anticipated (Figure 1b), indicating that PD-10 desalting column failed to completely remove MPAA/ascorbate. Fortunately, we found that the cyclization reaction could be completed within 30 min using only 1 equiv of MPAA without ascorbate. ${ }^{37}$ Simple ether extraction successfully removed MPAA, and a subsequent deselenization reaction could be completed within $3 \mathrm{~h}$ (Figure 1c).

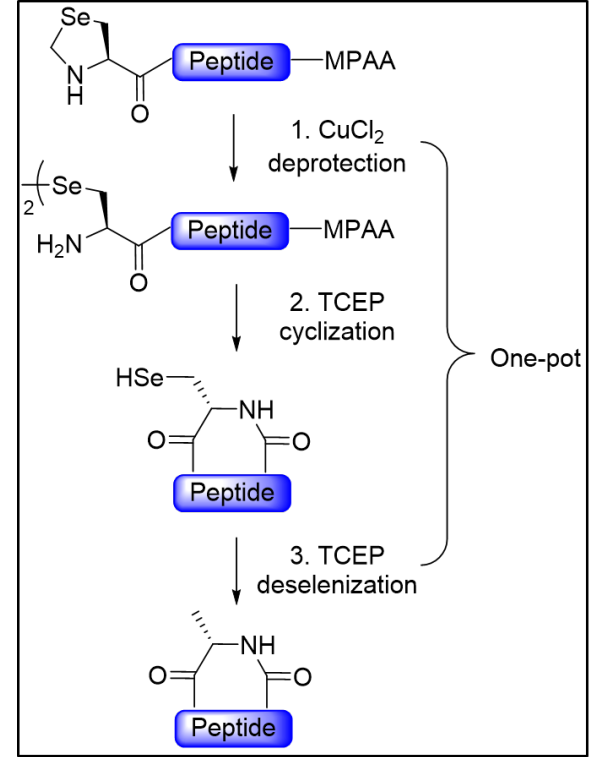

(a)

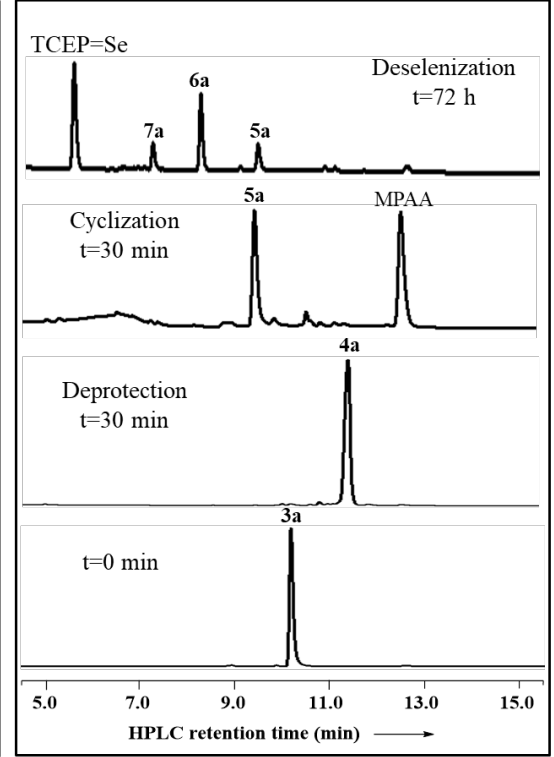

(b)

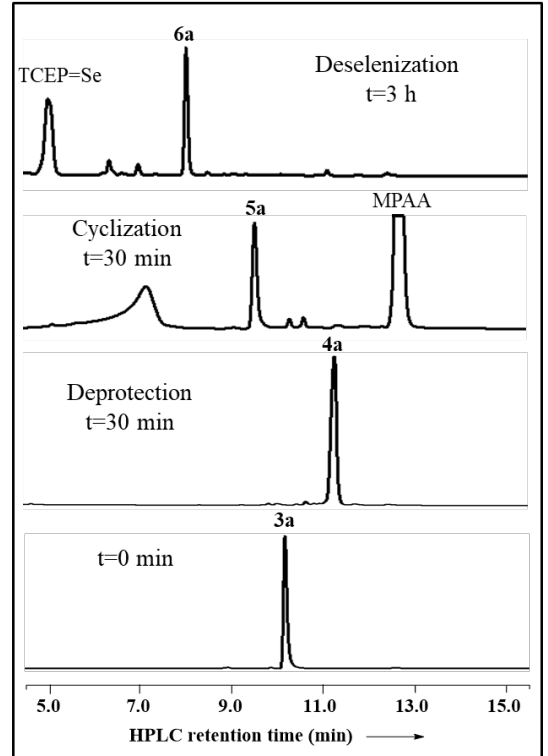

(c)

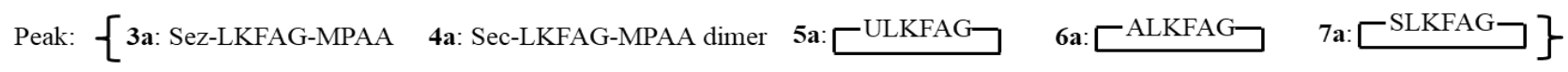

Figure 1. (a) The synthesis of cyclic peptide from Sez-peptide-MPAA in one-pot. Deprotection: 1.5 equiv $\mathrm{CuCl}_{2}$, pH 6 took 30 min; (b) Approach I: cyclization: TCEP (25 equiv), ascorbate (50 equiv), pH 7 took 30 min; deselenization: after PD-10 column, TCEP (200 equiv) at pH 5 was not over even after 72 h; (c) 
Approach II: cyclization: TCEP (5 equiv), MPAA (1 equiv), pH 7 took $30 \mathrm{~min}$; deselenization: after ether extraction, TCEP (200 equiv), pH 5 took $3 \mathrm{~h}$.

Encouraged by these results, peptide 3b (Sez-LKFAT-MPAA) was also tested using this approach. ${ }^{64}$ Under the same reaction conditions, however, only minimal cyclization product was observed and peptide $\mathbf{3 b}$ (with N-terminal Sez) was regenerated due to the slow cyclization reaction at B-branched C-terminal thioesters, in this case Thr (Figure S3). ${ }^{64}$ We note that the released formaldehyde ( 1 equiv) in the deprotection reaction, reacts again with the free $\mathrm{N}$-terminal Sec to regenerate Sez, which inhibited the cyclization reaction. When $\mathrm{MeONH}_{2}$ (5 equiv) was added to capture the released formaldehyde, no regeneration of $\mathbf{3 b}$ was observed, and the cyclization reaction was completed within $30 \mathrm{~min}$ (Figure S3). Following ether extraction to remove MPAA, the deselenization reaction was completed $(3 \mathrm{~h})$ and cyclic product $6 \mathbf{b}$ was isolated in $47 \%$ yield over the three steps (entry 2, Table 1). Further tests on four other representative peptides (3c-3f), in which Ala, Phe, Lys and Val were installed at the C-terminal, the target cyclic peptides (6c-6f) could be prepared in good isolated yields (39\%-68\%) under our optimized conditions (Table 1).

Table 1. One-pot deprotection, cyclization, and deselenization for six different representative peptides $^{\mathrm{a}}$

\begin{tabular}{|c|c|c|c|c|}
\hline \multicolumn{2}{|c|}{$\begin{array}{c}\text { Sez-LKFAX-MPAA } \\
\mathbf{3}\end{array}$} & \multicolumn{2}{|c|}{$\begin{array}{l}\text { 1. } \mathrm{CuCl}_{2} \text { ( } 1.5 \text { equiv), } \mathrm{pH} 6,30 \text { min } \\
\text { TCEP ( } 5 \text { equiv), MPAA ( } 1 \text { equiv) } \\
\mathrm{MeONH}_{2} \text { ( } 5 \text { equiv), } \mathrm{pH} 7,30 \text { min }\end{array}$} & $\frac{-\operatorname{ALKFAX} \square}{6}$ \\
\hline Entry & Peptides & Products & $\begin{array}{c}\text { Isolated yield } \\
(\%)\end{array}$ & $\begin{array}{c}\text { Average yield } \\
\text { per step (\%) }\end{array}$ \\
\hline 1 & $3 a ; X=G$ & $6 a$ & 68 & 88 \\
\hline 2 & $3 b ; X=T$ & $6 b$ & 47 & 78 \\
\hline 3 & $3 c ; X=A$ & $6 c$ & 67 & 88 \\
\hline 4 & $3 d ; X=F$ & $6 d$ & 59 & 84 \\
\hline $5^{\mathrm{b}}$ & $3 \mathbf{e} ; \mathrm{X}=\mathrm{K}$ & $6 e$ & 39 & 73 \\
\hline 6 & 3f; $X=V$ & $6 f$ & 55 & 82 \\
\hline
\end{tabular}

${ }^{a}$ All reactions were carried out in PB buffer $\left(0.2 \mathrm{M} \mathrm{NaH}_{2} \mathrm{PO}_{4}, 6 \mathrm{M} \mathrm{Gn} \cdot \mathrm{HCl}\right)$

${ }^{b}$ Cyclization conditions: $\mathrm{MeONH}_{2}$ (10 equiv) to inhibit the regeneration of $3 \mathbf{e}$. 
The unique chemistry of Sec not only allows its use in NCL and its chemoselective deselenization to Ala or Ser, ${ }^{37,39,41,43,44}$ but also can be used to enhance the oxidative folding of Cys-rich proteins without any major structural or biological function perturbation. ${ }^{41}$ To demonstrate the applicability of our protocol for the synthesis of cyclic proteins, we chose the Cys-rich cyclic protein Kalata S as target (Scheme 2a). Kalata $\mathrm{S}$ is a plant cyclotide, which is a unique family of cyclic cystine knotted proteins with a head-to-tail cyclized backbone. ${ }^{9,}{ }^{65}$ Kalata $\mathrm{S}$, also called Varv A, was isolated from $V$. arvensis Murray twenty years ago, ${ }^{66}$ although its exact function is still unknown, it differs from

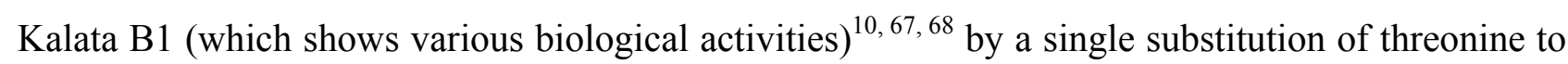
serine. $^{69}$

Like many members of the plant cyclotides, Kalata S contains six Cys residues in its sequence, which forms three disulfide bonds in its folded native state (Scheme 2). Four of these Cys residues are adjacent to $\beta$-branched residues (Thr and Val) that are not preferred for intramolecular NCL cyclization. $^{64}$ We chose the Gly-Cys site for NCL/cyclization (underlined in the sequence in Scheme 2a). We synthesized both wild-type (WT) Kalata S and its seleno-analogue Se-Kalata S, using our one-pot deprotection and cyclization strategy, followed by efficient oxidative folding (Scheme 2b).

(a)

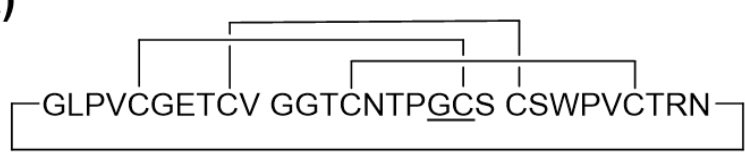

WT-Kalata S

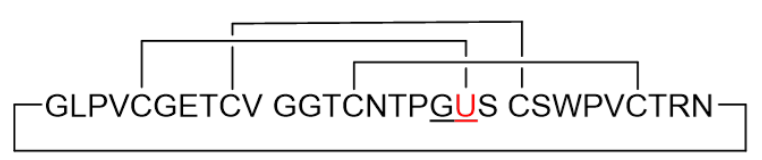

Se-Kalata S

(b)

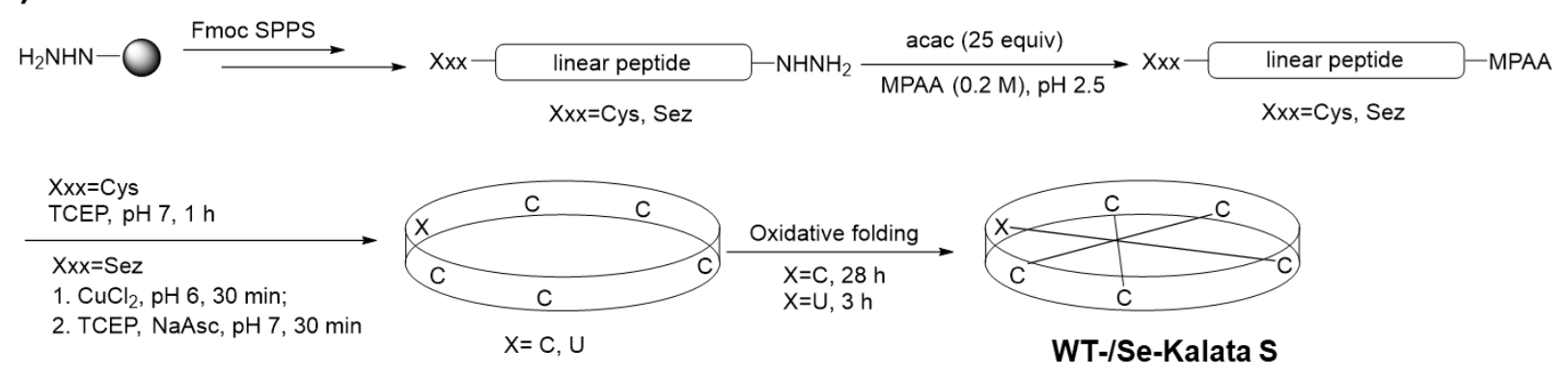

Scheme 2. Synthesis of WT-Kalata S and its seleno-analogue, Se-Kalata S. (a) The sequence of WT-Kalata $\mathrm{S}$ and Se-Kalata S. (b) The synthetic approach for the two cyclic proteins.

The linear peptide hydrazides of WT- and Se-Kalata S analogue (Scheme 2b) were readily 
synthesized on hydrazine-functionalized 2-chlorotrityl-resin by standard Fmoc-SPPS. ${ }^{70}$ Using the Knorr pyrazole method $^{71}$ for thioester formation, and subsequent NCL/cyclization, the WT-Kalata S was synthesized in $37 \%$ isolated yield (Scheme 2 and Figure 3a). For oxidative folding of WT-Kalata S, we used the established method for Kalata B1 folding, ${ }^{72}$ and the final folded state was obtained after $28 \mathrm{~h}$ in 57\% isolated yield (Figure 3a, and Figure S6).

For Se-Kalata S, the Sez-linear peptide-MPAA was also synthesized by using Knorr pyrazole method. ${ }^{71}$ The deprotection of $\mathrm{Sez}$ by $\mathrm{CuCl}_{2}$ at $\mathrm{pH} 6$ took 30 min, after which TCEP and ascorbate were added to the reaction mixture, and $\mathrm{pH}$ was adjusted to 7 to allow for the cyclization reaction to proceed, which was completed in $30 \mathrm{~min}$, giving Se-Kalata S in 40\% isolated yield for cyclization. Under the same reaction condition the oxidative folding of Se-Kalata S was roughly 10 times faster (3 h) than WT-Kalata S, with a similar $62 \%$ isolated yield of folded Se-Kalata S (Figure 3b, and Figure S9).

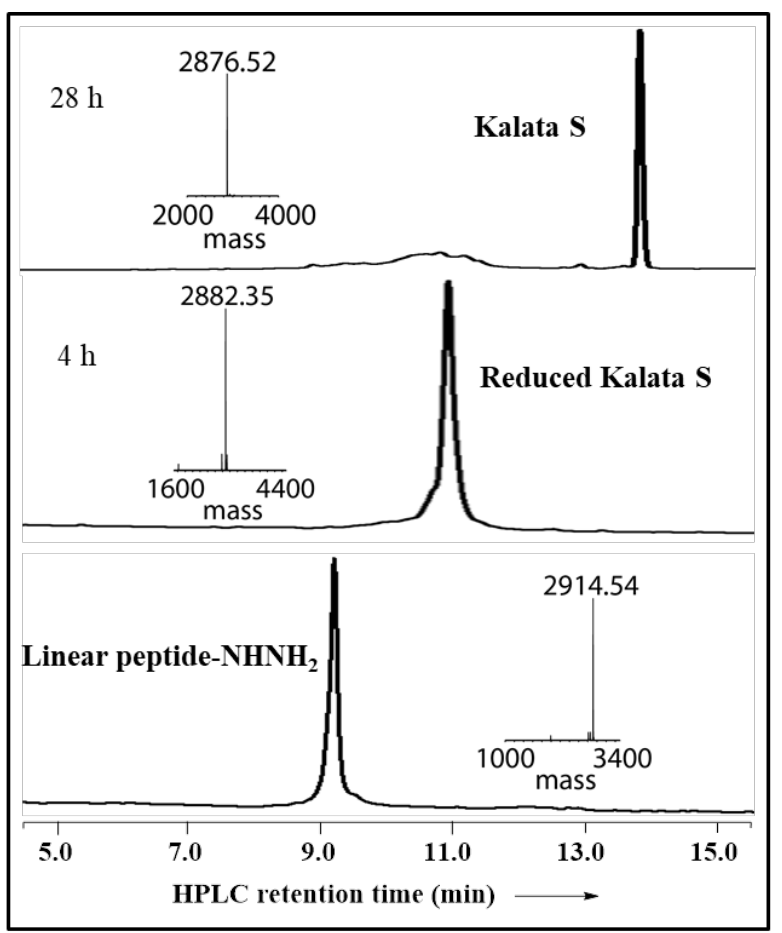

(a)

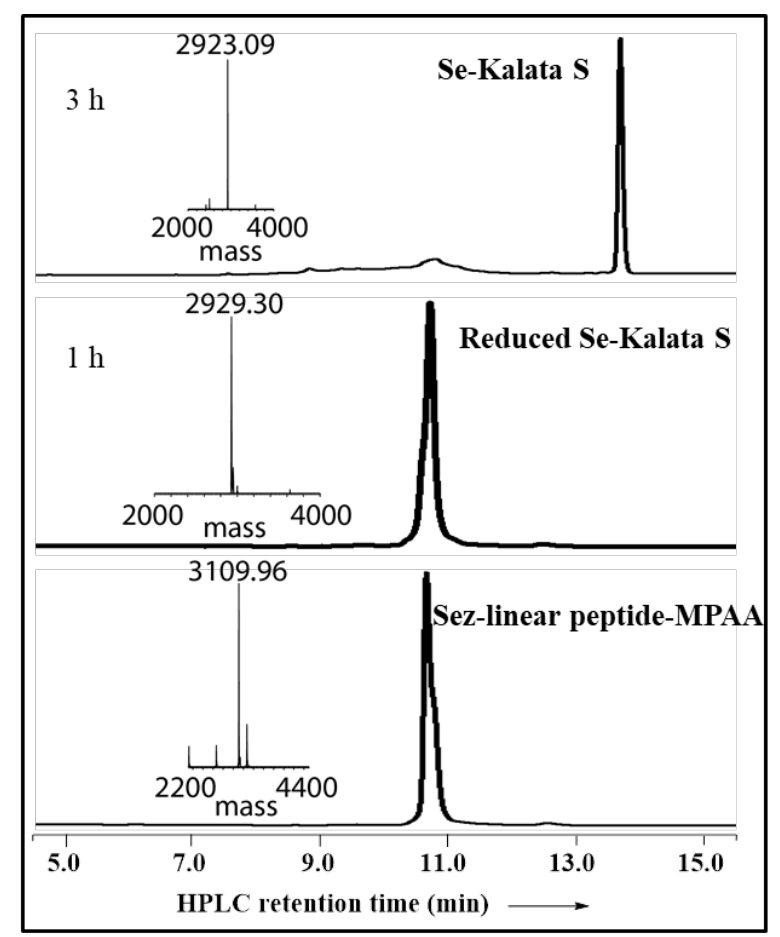

(b)

Figure 3. Synthesis of WT-Kalata S and its Se-analogue. Analytical HPLC and ESI-MS for the product in every step of (a) linear WT-Kalata $\mathrm{S}^{-} \mathrm{NHNH}_{2}$ (obs. 2914.54 Da, calc. $2914.21 \mathrm{Da}$ ), reduced cyclic WT-Kalata S (obs. 2882.35 Da, calc. 2882.17 Da), folded WT-Kalata S (obs. 2876.52 Da, calc. 2876.13 Da); and (b) Sez-linear peptide-MPAA (obs. $3109.96 \mathrm{Da}$, calc. $3110.14 \mathrm{Da}$ ), reduced cyclic Se-Kalata S (obs. 2929.30 Da, calc. 2930.12 Da), folded Se-Kalata S (obs. 2923.09 Da, calc. 2924.07 Da). 
In summary, we used our recently developed copper-mediated deprotection of Sez for the preparation of cyclic peptides and proteins. After deprotection, the intramolecular cyclization reaction was smoothly completed in a one-pot fashion. We could then implement deselenization of cyclic selenopeptides without intermediate HPLC-purification. Using this approach, a variety of cyclic peptides were prepared in good isolated yields. Furthermore, the good performance of both deprotection and cyclization steps were highlighted in one-pot synthesis of Se-Kalata S, in which the presence of Sec in its sequence accelerated oxidative folding compared with wild-type Kalata S. These advances provide new tools for chemical synthesis of cyclic peptides and proteins.

\section{EXPERIMENTAL SECTION}

General Methods and Materials. Solvents and reagents. Buffers were prepared using MilliQ water (Millipore, Merck). Disodium hydrogen phosphate dodecahydrate $\left(\mathrm{Na}_{2} \mathrm{HPO}_{4} \cdot 12 \mathrm{H}_{2} \mathrm{O}\right)$, 4-mercaptophenylacetic acid (MPAA), N,N'-Diisopropylcarbodiimide (DIC), triisopropylsilane (TIPS), acetylacetone (acac), DL-dithiothreitol (DTT), tris(2-carboxyethyl)phosphine hydrochloride (TCEP· $\mathrm{HCl}$ ), sodium ascorbate, concentrated $\mathrm{HNO}_{3}$ were purchased from Sigma-Aldrich. Ultrapure guanidinium chloride ( $\mathrm{Gn} \cdot \mathrm{HCl}$, MP Biomedicals, LLC, France) was used in all cyclization reactions. All Fmoc-amino acids were obtained from Matrix Innovation (Quebec City, Canada), with the following side chain protecting groups: $\operatorname{Arg}(\mathrm{Pbf}), \mathrm{Glu}(\mathrm{O} t \mathrm{Bu}), \operatorname{Ser}(t \mathrm{Bu}), \operatorname{Thr}(t \mathrm{Bu}), \operatorname{Cys}(\operatorname{Trt})$, Lys(Boc), Trp(Boc), Asn(Trt). TentaGel ${ }^{\circledR}$ R RAM resin (loading $0.18 \mathrm{mmol} / \mathrm{g}$ ), Rink amide resin (loading 0.3 0.6 mmol $/ \mathrm{g}$ ), Wang resin (loading $0.3 \sim 0.8 \mathrm{mmol} / \mathrm{g}$ ) and Chlorotrityl resin (loading 1.8 $\mathrm{mmol} / \mathrm{g}$ ) were purchased from Rapp Polymer GmbH (Germany), GL Biochemical (China) or Chem-impex (USA). $\quad N, N, N^{\prime}, N^{\prime}$-Tetramethyl-O-(6-chloro-1H-benzotriazol-1-yl) uronium hexafluorophosphate (HCTU) and Ethyl cyano(hydroxyimino)acetate (OxymaPure) were purchased from Luxembourg Biotechnologies Ltd. (Rehovot, Israel). All solvents: $N, N$-dimethylformamide (DMF), Diethyl ether $\left(\mathrm{Et}_{2} \mathrm{O}\right)$, hydrochloric acid $(\mathrm{HCl})$, ethyl acetate, dichloromethane (DCM), acetonitrile (MeCN), N,N-diisopropylethyl amine (DIEA), Trifluoroacetic acid (TFA) and piperidine (Pip) were purchased from Bio-Lab (Jerusalem, Israel) and were peptide synthesis, HPLC or ULC-grade. Boc-Sez-OH synthesis was reported previously. ${ }^{39}$

Analyses and methods. High Performance Liquid Chromatography (HPLC). Analytical reversed-phase (RP) HPLC analyses were performed on a Waters Alliance HPLC with UV detection $(220 \mathrm{~nm}$ and $280 \mathrm{~nm})$ using a XSelect C18 column $(3.5 \mu \mathrm{m}, 130 \AA, 4.6 \times 150 \mathrm{~mm})$. Preparative and semi-preparative RP-HPLC were performed on a Waters 150 Q LC system using a XSelect C18 column $(5 \mu \mathrm{m}, 30 \times 250 \mathrm{~mm})$ and XSelect $\mathrm{C} 18$ column $(5 \mu \mathrm{m}, 10 \times 150 \mathrm{~mm})$. Linear gradients of $\mathrm{MeCN}$ (with $0.1 \%$ TFA, buffer B) in water (with $0.1 \%$ TFA, buffer A) were used for all systems to elute bound peptides. The flow rates were $1 \mathrm{~mL} / \mathrm{min}$ (analytical, column heated at $30{ }^{\circ} \mathrm{C}$ ), $3.4 \mathrm{~mL} / \mathrm{min}$ (semi-preparative), and $20 \mathrm{~mL} / \mathrm{min}$ (C18 preparative).

\section{Electrospray Ionization Mass Spectrometry (ESI-MS) and High-Resolution Mass}


Spectrometry (HR-MS). ESI-MS was performed on LCQ Fleet Ion Trap mass spectrometer (Thermo Scientific) in the positive mode. Peptide masses were calculated from the experimental mass to charge $(\mathrm{m} / \mathrm{z})$ ratios from the observed multiply charged species of a peptide. The HR-MS were recorded on a Q Exactive hybrid quadrupole-Orbitrap mass spectrometer (Thermo Scientific) with a ESI source with 140'000 FWHM, a method that the AGC target was set to 1e6, and scan range was $400-2800 \mathrm{~m} / \mathrm{z}$. The raw data was deconvoluted by the MagTran v1.03.

Inductively Coupled Plasma Mass Spectrometer (ICP-MS). Trace copper analyses were performed on an Agilent 7500cx Inductively Coupled Plasma Mass Spectrometer (ICP-MS). Sample preparation and chemical analysis were performed in the clean laboratory of the Institute of Earth Sciences at the Hebrew University of Jerusalem. The peptides and proteins were digested in concentrated $\mathrm{HNO}_{3}$ for $36 \mathrm{~h}$, and diluted to $1 \% \mathrm{HNO}_{3}$ solution with distilled water. Before the analysis, the ICP-MS was calibrated with a series of multielement standard solutions (Merck; ME VI). The contribution of metals by the reagents used in the procedures was determined by measuring procedural blanks. The precision and accuracy of the ICP-MS were $\pm 5 \%$.

The determination of protein concentration. The solutions of WT-Kalata S and Se-Kalata S served as stock and their concentrations were determined by UV-Vis spectrophotometer (using theoretical molar extinction coefficient of $\varepsilon_{280 \mathrm{~nm}}=5690 \mathrm{M}^{-1} \mathrm{~cm}^{-1}$ for the two proteins).

Circular Dichroism (CD). The secondary structure content of WT-Kalata S and Se-Kalata S were compared using UV CD spectroscopy (200 to $320 \mathrm{~nm}$ ). CD spectra of these variants (30 $\mu \mathrm{M}$ for WT-Kalata $\mathrm{S}$ and Se-Kalata $\mathrm{S}$ ) were recorded at $25{ }^{\circ} \mathrm{C}$ in $\mathrm{NH}_{4} \mathrm{HCO}_{3}$ buffer solution $(50 \mathrm{mM}$ $\mathrm{NH}_{4} \mathrm{HCO}_{3} ; 10 \mathrm{mM} \mathrm{GSH}$, pH 7.5 containing $\left.50 \% i \mathrm{PrOH}\right)$ in a quartz cuvette with a path length of $0.1 \mathrm{~cm}$ using a J-810 spectropolarimeter (Jasco). Spectra were obtained by averaging 5 wavelength scans from 200 to $320 \mathrm{~nm}$ in $1 \mathrm{~nm}$ steps, with a signal averaging time of $2 \mathrm{~s}$ and a bandwidth of 1 $\mathrm{nm}$. As shown in Figure S26, the UV CD spectra of folded WT-Kalata S and Se-Kalata S are similar.

General procedure for Fmoc solid-phase peptide synthesis. Peptides were synthesized manually by Fmoc-SPPS typically on a $0.25 \mathrm{mmol}$ scale. Fmoc-deprotection was carried out with $20 \%$ piperidine in DMF $(10 \mathrm{~min} \times 2)$. Fmoc-amino acids ( $1 \mathrm{mmol}$ in $5 \mathrm{~mL} \mathrm{DMF}, 4$ equiv) activated with HATU ( $1 \mathrm{mmol}$ in $5 \mathrm{~mL} \mathrm{DMF,} 4$ equiv) and DIEA ( $2 \mathrm{mmol}$ in $5 \mathrm{~mL} \mathrm{DMF}, 8$ equiv) for $5 \mathrm{~min}$ and allowed to couple for $30 \mathrm{~min}$, with constant shaking. Sez coupling was performed by DIC/OxymaPure procedure using 2 equiv of Boc-Sez-OH.1 The resulting resins were washed with $\operatorname{DMF}(\mathrm{x} 3)$ and DCM (x3) and methanol (x3) and dried.

General procedure for synthesis of peptide thioesters. The peptide thioesters were synthesized first on Fmoc-(Me)Dbz-resin ( 0.25 mmol scale). Fmoc-(Me)Dbz-OH (3 equiv) ${ }^{61,62}$ activated with HCTU (3 equiv)/DIEA (6 equiv) in DMF was doubly coupled to the free amine of TentaGel ${ }^{\circledR} \mathrm{R}$ RAM resin $(0.18 \mathrm{mmol} / \mathrm{g}, 0.25 \mathrm{mmol} \mathrm{scale})$ for $1 \mathrm{~h}$. Sez was manually doubly coupled for $2 \mathrm{~h}(3.0$ equiv Boc-Sez-OH activated on ice for 5 min using 3.0 equiv OxymaPure and 2.9 equiv DIC).

On resin (Me) $\mathrm{Nbz}$ formation $^{62}$ : After synthesis completion, the resin was washed well with DMF and DCM and dried well under vacuum. A solution of $p$-nitrophenyl chloroformate (5 equiv) in 
DCM (10 mL/0.125 mmol resin) was then added, shaken for $2 \mathrm{~h}$ at room temperature and washed with DCM $(3 \times 5 \mathrm{~mL})$ and DMF $(3 \times 5 \mathrm{~mL})$. This step was repeated one more time. Next, $5 \mathrm{~mL}$ of 0.5 M DIEA in DMF was added and shaken for additional $1 \mathrm{~h}$ to complete Nbz formation (repeated twice), and washed well with DMF $(3 \times 5 \mathrm{~mL})$, DCM $(3 \times 5 \mathrm{~mL})$ and dried under vacuum.

Deprotection and cleavage: The peptide was cleaved off resin using TFA:triisopropylsilane (TIPS): $\mathrm{H}_{2} \mathrm{O}$ (95:2.5:2.5) cocktail for $2 \mathrm{~h}$ at room temperature. The cleavage mixture was filtered and the resin was washed with TFA. The combined solutions were concentrated by $\mathrm{N}_{2}$ bubbling, to which 8-fold volume of cold ether was added dropwise. The precipitated crude peptides were centrifuged, ether was removed and the crude peptides dissolved in $\mathrm{MeCN}$-water (1:1) containing $0.1 \% \mathrm{TFA}$ and was further diluted to $\sim 25 \% \mathrm{MeCN}$ with water and lyophilized.

Procedure of thioseterification: The dried crude peptides were dissolved in $20 \mathrm{~mL}$ PB buffer $(0.2 \mathrm{M}$ sodium phosphate, $6 \mathrm{M} \mathrm{Gn} \cdot \mathrm{HCl}, \mathrm{pH}$ 7) and treated with 5\% MMP (Methyl 3-mercaptopropionate) or $200 \mathrm{mM}$ MPAA (4-Mercaptophenylacetic acid) for $1 \mathrm{~h} \sim 2 \mathrm{~h}$ at room temperature. The reaction was monitored by analytical HPLC (XSelect C18 column, $3.5 \mu \mathrm{m}, 130 \AA, 4.6 \times 150 \mathrm{~mm}$ ) at $220 \mathrm{~nm}$, and confirmed by ESI-MS. The peptide thioesters were purified by preparative RP-HPLC, using a gradient of $25-45 \%$ B over $51 \mathrm{~min}$.

\section{$\mathrm{MeONH}_{2}$ deprotects $\mathrm{Sez}$ and reacts with the thioester to give 2}

Peptide 1 (1.6 mg, $2 \mu \mathrm{mol}$, final conc. $2 \mathrm{mM}$ ) was dissolved in $1 \mathrm{~mL}$ PB buffer $\left(0.2 \mathrm{M} \mathrm{NaH}_{2} \mathrm{PO}_{4}, 6\right.$ $\mathrm{M} \mathrm{Gn} \cdot \mathrm{HCl}, 0.2 \mathrm{M} \mathrm{MeONH}_{2}, \mathrm{pH} 4.5$ ) at room temperature. After $17 \mathrm{~h}$, peptide 2 was formed in $95 \%$ yield (HPLC) (Figure S1). The progress of reaction was followed by analytical HPLC using a XSelect C18 column $(3.5 \mu \mathrm{m}, 130 \AA, 4.6 \times 150 \mathrm{~mm})$ at $220 \mathrm{~nm}$.

\section{One-pot $\mathrm{Cu}$ (II)-mediated deprotection of Sez, cyclization and deselenization for the synthesis} of cyclic peptides. Three one-pot deprotection, cyclization and deselenization strategies were investigated (Figure S3). (I): 1.5 equiv $\mathrm{CuCl}_{2}$ was added to $500 \mu \mathrm{L}$ PB buffer $\left(0.2 \mathrm{M} \mathrm{NaH}_{2} \mathrm{PO}_{4}, 6\right.$ $\mathrm{M} \mathrm{Gn} \cdot \mathrm{HCl}, \mathrm{pH} 6)$, and peptide 3a $(2 \mu \mathrm{mol})$ was then added to the buffer. The reaction mixture was shacked every five minutes under aerobic conditions. After $30 \mathrm{~min}, 7.1 \mathrm{mg}$ TCEP (0.05 M) and 9.9 mg sodium ascorbate $(0.1 \mathrm{M})$ were added to the reaction mixture and retained at $\mathrm{pH} 7$ (adjusted with $1 \mathrm{M} \mathrm{NaOH}$ ). The cyclization reaction was completed within $30 \mathrm{~min}$. (II): 1.5 equiv $\mathrm{CuCl}_{2}$ was added to $500 \mu \mathrm{L}$ of the same PB buffer, and peptide 3a $(2 \mu \mathrm{mol})$ was then added to the above buffer. The reaction mixture was shaken every five minutes. After $30 \mathrm{~min}, 100 \mu \mathrm{L}$ TCEP (5 equiv) and MPAA (1 equiv) solution was added to the reaction mixture and retained at $\mathrm{pH} 7$ (adjusted with 1 $\mathrm{M} \mathrm{NaOH})$. The cyclization reaction was completed within $30 \mathrm{~min}$. The reaction mixture was extracted three times by ether, TCEP (200 equiv) was added to the reaction mixture and deselenization reaction was completed within $3 \mathrm{~h}$ at $\mathrm{pH} 5$ (adjusted with $1 \mathrm{M} \mathrm{NaOH}$ ) under the argon atmosphere, giving the desired cyclic peptide c(ALKFAG) as the major product. (III) 1.5 equiv $\mathrm{CuCl}_{2}$ was added to $500 \mu \mathrm{L}$ of the same PB buffer, and $\mathbf{3 b}(2 \mu \mathrm{mol})$ was then added to the above buffer. The reaction mixture was shacked every five minutes. After $30 \mathrm{~min}, 100 \mu \mathrm{L}$ TCEP (5 equiv), MPAA (1 equiv) and $\mathrm{MeONH}_{2}$ (5 equiv) solution was added to the reaction mixture and retained $\mathrm{pH} 7$ (with $1 \mathrm{M} \mathrm{NaOH}$ ). The cyclization reaction was completed within 30 min under these conditions. The reaction mixture was extracted three times by ether, TCEP (200 equiv) was added to the reaction mixture and deselenization reaction could be completed within $3 \mathrm{~h}$ at $\mathrm{pH} 5$ (adjusted with $1 \mathrm{M} \mathrm{NaOH}$ ) under argon atmosphere giving the desired cyclic peptide c(ALKFAT) as the 
major product. The progress of reactions were monitored by analytical HPLC (linear gradient of 5\% to $70 \% \mathrm{~B}$ over $25 \mathrm{~min}, 1 \mathrm{~mL} / \mathrm{min})$ using a XSelect C18 column $(3.5 \mu \mathrm{m}, 130 \AA, 4.6 \times 150 \mathrm{~mm})$ at $220 \mathrm{~nm}$.

General procedure for the synthesis of cyclic peptide. 1.5 equiv $\mathrm{CuCl}_{2}$ was incubated in $500 \mu \mathrm{L}$ PB buffer $\left(0.2 \mathrm{M} \mathrm{NaH}_{2} \mathrm{PO}_{4}, 6 \mathrm{M} \mathrm{Gn} \cdot \mathrm{HCl}, \mathrm{pH} 6\right)$ for $5 \mathrm{~min}$, peptide thioesters $(2 \mu \mathrm{mol})$ were then added to the above buffer. The reaction mixture was shacked every five minutes. After $30 \mathrm{~min}, 100$ $\mu \mathrm{L}$ TCEP ( 5 equiv), MPAA ( 1 equiv) and $\mathrm{MeONH}_{2}$ ( 5 equiv) solution was added to the reaction mixture and retained $\mathrm{pH} 7$ (adjusted with $1 \mathrm{M} \mathrm{NaOH}$ ). The cyclization reaction could be completed within $30 \mathrm{~min}$. The reaction mixture was extracted three times by ether, TCEP (200 equiv) was added to the reaction mixture and deselenization reaction could be completed within $3 \mathrm{~h}$ at $\mathrm{pH} 5$ (adjusted with $1 \mathrm{M} \mathrm{NaOH}$ ) under argon atmosphere. The progress of reactions was monitored by analytical HPLC (linear gradient of $5 \%$ to $70 \%$ B over $25 \mathrm{~min}, 1 \mathrm{~mL} / \mathrm{min}$ ) using a XSelect C18 column $(3.5 \mu \mathrm{m}, 130 \AA, 4.6 \times 150 \mathrm{~mm})$ at $220 \mathrm{~nm}$. Isolated yields were calculated based on the amount of each peptide thioester used.

\section{The synthesis of WT-Kalata $\mathrm{S}$}

The synthesis of linear WT-Kalata $S$ was carried out on hydrazide functionalized chlorotrityl resin ( $1.8 \mathrm{mmol} / \mathrm{g}, 0.25 \mathrm{mmol} \mathrm{scale})$ on automated peptide synthesizer. Chlorotrityl resin $(1.8 \mathrm{mmol} / \mathrm{g}$, $0.25 \mathrm{mmol}$ scale) was swelled in DMF for $1 \mathrm{~h}$. The resin was doubly treated with freshly prepared $10 \%$ hydrazine in DMF for $30 \mathrm{~min}$ and drained. The resin was washed well with DMF and then treated with $10 \% \mathrm{MeOH}$ in DMF for $30 \mathrm{~min}$. Subsequent steps were completed with standard machine assisted Fmoc-SPPS. After peptide chain assembly, the resin was washed well with DMF/DCM, and dried under vacuum. The peptide was cleaved using TFA:water:TIS (95\%: 2.5\%: $2.5 \%$ ) cocktail for $2 \mathrm{~h}$. The cleavage mixture was filtered and washed by TFA. The combined solution was concentrated with $\mathrm{N}_{2}$ bubbling, to which 8-fold volume of cold ether was added dropwise. The precipitated crude peptide was centrifuged (5000 rpm, $10 \mathrm{~min}$ ), ether was removed and the crude peptide dissolved in $\mathrm{MeCN}$-water $(1: 1)$ containing $0.1 \%$ TFA and was further diluted to $\sim 25 \% \mathrm{MeCN}$ with water and lyophilized. The crude peptide were dissolved in $\mathrm{MeCN} / \mathrm{H}_{2} \mathrm{O}$ and purified by prep RP-HPLC (XSelect C18 column: $5 \mu \mathrm{m}, 30 \times 250 \mathrm{~mm}$ ) using a gradient of $28-48 \%$ $\mathrm{B}$ over $50 \mathrm{~min}$ at $220 \mathrm{~nm}$. The isolated yield was $20 \%$. The objective peak was determined by ESI-MS (obs. 2914.54 Da, calc. 2914.21 Da, Figure S4).

Cyclization of linear WT-Kalata $\mathrm{S}-\mathrm{NHNH}_{2}$ : The WT-Kalata S-NHNH $2(0.7 \mu \mathrm{mol}, 2.1 \mathrm{mg})$ was dissolved in $700 \mu \mathrm{L}$ PB buffer $\left(0.2 \mathrm{M} \mathrm{NaH}_{2} \mathrm{PO}_{4}, 6 \mathrm{M} \mathrm{Gn} \cdot \mathrm{HCl}, 200 \mathrm{mM}\right.$ MPAA, pH 2.5), 10 equiv acetylacetone (acac) was added to the mixture and he reaction mixture was held at room temperature for 3 hours. The $\mathrm{pH}$ of the reaction mixture was adjusted to 7 with $1 \mathrm{M} \mathrm{NaOH}$. The cyclization reaction was complete within $1 \mathrm{~h}$. The reduced cyclic WT-Kalata S was obtained in 37\% isolated yield $(0.26 \mu \mathrm{mol}, 0.75 \mathrm{mg})$ after purification by semi-preparative RP-HPLC (XSelect C18 column: $5 \mu \mathrm{m}, 10 \times 150 \mathrm{~mm}$ ) using a gradient of $5-70 \% \mathrm{~B}$ over $20 \mathrm{~min}$. The product was characterized by ESI-MS analysis (obs. 2882.35 Da, calc. 2882.17 Da, Figure S5).

Oxidative folding of the reduced Kalata $S^{72}$. The purified reduced cyclic WT-Kalata S $(0.6 \mathrm{mg}, 0.21$ $\mu \mathrm{mol}$, final concentration $0.42 \mathrm{mM}$ ) was oxidatively folded in the presence of reduced glutathione (10 mM; GSH) in $\mathrm{NH}_{4} \mathrm{HCO}_{3}$ buffer solution (50 mM NH $\mathrm{NCO}_{3} ; \mathrm{pH} 7.5$ containing $50 \% i \mathrm{PrOH}$ ). Under these conditions, the reduced Kalata $\mathrm{S}$ was converted to the native structure quantitatively 
(>95\%) within $28 \mathrm{~h}$. The product was isolated in 57\% yield and characterized by ESI-MS analysis (obs. $2876.52 \mathrm{Da}$, calc. 2876.13 Da, Figure S6).

\section{The synthesis of Se-Kalata $\mathbf{S}$}

The synthesis of linear Se-Kalata $S$ was similar to the synthesis of linear WT-Kalata S, on hydrazide functionalized chlorotrityl resin $(1.8 \mathrm{mmol} / \mathrm{g}, 0.25 \mathrm{mmol}$ scale $)$ and by automated peptide synthesizer, except that Boc-Sez-OH was coupled at the N-terminal. Sez was manually doubly coupled for $2 \mathrm{~h}$ (3.0 equiv Boc-Sez-OH activated on ice for 5 min using 3.0 equiv OxymaPure and 2.9 equiv DIC). After peptide chain assembly, the resin was washed well with DMF and DCM, and dried under vacuum. The peptide was cleaved using TFA:water:TIS (95\%: 2.5\%: 2.5\%) cocktail for $2 \mathrm{~h}$. The cleavage mixture was filtered and washed by TFA. The combined solution was concentrated with $\mathrm{N}_{2}$ bubbling, to which 8-fold volume of cold ether was added dropwise. The precipitated crude peptide was centrifuged $(5000 \mathrm{rpm}, 10 \mathrm{~min})$, ether was removed and the crude peptide dissolved in $\mathrm{MeCN} / \mathrm{H}_{2} \mathrm{O}$ (1:1) containing $0.1 \%$ TFA and was further diluted to $25 \%$ $\mathrm{MeCN}$ with water and lyophilized.

Thioesterification of Sez-Kalata $\mathrm{S}-\mathrm{NHNH}_{2}$ : The crude C-terminal hydrazide peptide was converted to the C-terminal MPAA thioester using the same procedure as for WT-Kalata S. The Sez-Kalata S-MPAA was obtained in 5\% isolated yield $(12.5 \mu \mathrm{mol}, 39 \mathrm{mg})$ after purification by preparative RP-HPLC (XSelect C18 column: $5 \mu \mathrm{m}, 30 \times 250 \mathrm{~mm}$, at $220 \mathrm{~nm}$ ) using a gradient of $25-45 \% \mathrm{~B}$ over $30 \mathrm{~min}$. The product was characterized by ESI-MS analysis (obs. $3109.96 \mathrm{Da}$, calc. 3110.14 $\mathrm{Da}$, Figure S7).

Cyclization of Sez-Kalata S-MPAA: 1.5 equiv $\mathrm{CuCl}_{2}(2.1 \mu \mathrm{mol}, 0.3 \mathrm{mg})$ was added to $500 \mu \mathrm{L} \mathrm{PB}$ buffer $\left(0.2 \mathrm{M} \mathrm{NaH}_{2} \mathrm{PO}_{4}, 6 \mathrm{M} \mathrm{Gn} \cdot \mathrm{HCl}, \mathrm{pH}\right.$ 6) and Sez-Kalata S-MPAA (0.7 $\mu$ mol, $\left.2.2 \mathrm{mg}\right)$ was added to the above buffer at room temperature. The reaction mixture was shacked every five minutes. The deprotection reaction was completed within $30 \mathrm{~min} .14 .3 \mathrm{mg}$ TCEP (50 $\mu \mathrm{mol}, 71$ equiv) and $19.8 \mathrm{mg}(100 \mu \mathrm{mol}, 142$ equiv) sodium ascorbate were added to the reaction mixture and the $\mathrm{pH}$ of reaction system was adjusted to 7 (with $1 \mathrm{M} \mathrm{NaOH}$ ). After $30 \mathrm{~min}$, the cyclization reaction was completed, and 50 equiv DTT was added to the reaction mixture to get reduced Se-Kalata $\mathrm{S}$. The reduced cyclic Se-Kalata $\mathrm{S}$ was obtained in $40 \%$ isolated yield $(0.28 \mu \mathrm{mol}, 0.8 \mathrm{mg})$ after purification by semi-preparative RP-HPLC (XSelect C18 column: $5 \mu \mathrm{m}, 10 \times 150 \mathrm{~mm}$, at 220 $\mathrm{nm}$ ) using a gradient of $25-45 \% \mathrm{~B}$ over $30 \mathrm{~min}$. The product was characterized by ESI-MS analysis (obs. 2929.30 Da, calc. 2930.12 Da, Figure S8).

Oxidative folding of the reduced Se-Kalata $S$ : The purified reduced cyclic Se-Kalata S (0.6 mg, 0.2 $\mu \mathrm{mol}$, final concentration $0.4 \mathrm{mM}$ ) was oxidatively folded in the presence of reduced glutathione (10 mM; GSH) in $\mathrm{NH}_{4} \mathrm{HCO}_{3}$ buffer solution $(50 \mathrm{mM}$; $\mathrm{pH} 7.5$ containing $50 \% \mathrm{iPrOH})$. Under these conditions, the reduced Se-Kalata S was converted to the native structures quantitatively ( $>97 \%)$ within 3 h. The product was characterized by ESI-MS analysis (obs. 2923.09 Da, calc. 2924.07 Da, Figure S9).

\section{ASSOCIATED CONTENT}

\section{Supporting Information}

The Supporting Information is available free of charge on the ACS Publications website at DOI: HPLC chromatograms, LC- MS, HRMS and CD spectra of products (PDF) 


\section{AUTHOR INFORMATION}

\section{Corresponding Author}

*E-mail: Metanis@mail.huji.ac.il

\section{ORCID}

Zhenguang Zhao: 0000-0003-2723-802X

Norman Metanis: 0000-0002-6373-9318

\section{Notes}

The authors declare no competing financial interest.

\section{ACKNOWLEDGMENTS}

We would like to thank Dr. Shailesh Kumar, Ms. Reem Mousa, Ofir Tirosh and Prof. Yigal Erel for technical assistance and helpful discussions. We also thank Mrs. Ricki Notis Dardashti for input on the manuscript. Z.Z. is grateful for a CSC fellowship. N.M. acknowledges the financial support of Israel Science Foundation (783/18) and ICRF Acceleration Grant.

\section{References}

1. Zasloff, M. Nature 2002, 415, 389.

2. Trabi, M.; Craik, D. J. Trends Biochem. Sci. 2002, 27, 132-138.

3. Andrew, T. B.; Cayla, M. M.; Lokey, R. S. Curr. Top. Med. Chem. 2013, 13, 821-836.

4. Villar, E. A.; Beglov, D.; Chennamadhavuni, S.; Porco Jr, J. A.; Kozakov, D.; Vajda, S.; Whitty, A. Nat. Chem. Biol. 2014, 10, 723.

5. Yudin, A. K. Chem. Sci. 2015, 6, 30-49.

6. Cardote, T. A. F.; Ciulli, A. Chemmedchem 2016, 11, 787-794.

7. Abdalla, M. A.; McGaw, L. J. Molecules 2018, 23.

8. Moore, R. E. J. Ind. Microbiol. 1996, 16, 134-143.

9. Craik, D. J.; Daly, N. L.; Bond, T.; Waine, C. J. Mol. Biol. 1999, 294, 1327-1336.

10. Daly, N. L.; Rosengren, K. J.; Craik, D. J. Ad. Drug Deliv. Rev. 2009, 61, 918-930.

11. Ravipati, A. S.; Poth, A. G.; Troeira Henriques, S.; Bhandari, M.; Huang, Y.-H.; Nino, J.; Colgrave, M. L.; Craik, D. J. J. Nat. Prod. 2017, 80, 1522-1530.

12. Joo, S. H. Biomol. Ther. 2012, 20, 19-26.

13. Thapa, P.; Espiritu, M. J.; Cabalteja, C.; Bingham, J.-P. Int. J. Pept. Res. Ther. 2014, 20, 545-551.

14. Ojeda, P. G.; Cardoso, M. H.; Franco, O. L. Drug Discov. Today 2019, doi: 10.1016/j.drudis.2019.09.010.

15. Kessler, H. Angew. Chem. Int. Ed. 1982, 21, 512-523.

16. Craik, D. J. Science 2006, 311, 1563-1564.

17. McMurray, J. S. Tetrahedron Lett. 1991, 32, 7679-7682.

18. Yang, L.; Morriello, G. Tetrahedron Lett. 1999, 40, 8197-8200.

19. Qin, C.; Zhong, X.; Ng, N. L.; Bu, X.; Chan, W. S.; Guo, Z. Tetrahedron Lett. 2004, 45, 217-220.

20. Zhao, J.-F.; Zhang, X.-H.; Ding, Y.-J.; Yang, Y.-S.; Bi, X.-B.; Liu, C.-F. Org. Lett. 2013, 15, 5182-5185.

21. Valeur, E.; Bradley, M. Chem. Soc. Rev. 2009, 38, 606-631.

22. Botti, P.; Pallin, T. D.; Tam, J. P. J. Am. Chem. Soc. 1996, 118, 10018-10024.

23. A. Camarero, J.; W. Muir, T. Chem. Commun. 1997, 1369-1370.

24. Zhang, L.; Tam, J. P. J. Am. Chem. Soc. 1997, 119, 2363-2370. 
25. Tulla-Puche, J.; Barany, G. J. Org. Chem. 2004, 69, 4101-4107.

26. Hamada, Y.; Shioiri, T. Chem. Rev. 2005, 105, 4441-4482.

27. Kleineweischede, R.; Hackenberger, C. P. R. Angew. Chem. Int. Ed. 2008, 47, 5984-5988.

28. Fukuzumi, T.; Ju, L.; Bode, J. W. Org. Biomol. Chem. 2012, 10, 5837-5844.

29. Zheng, J. S.; Tang, S.; Guo, Y.; Chang, H. N.; Liu, L. Chembiochem 2012, 13, 542-546.

30. Lee, C. L.; Lam, H. Y.; Li, X. Nat. Prod. Rep. 2015, 32, 1274-1279.

31. Dawson, P. E.; Muir, T. W.; Clarklewis, I.; Kent, S. B. H. Science 1994, 266, 776-779.

32. Yan, L. Z.; Dawson, P. E. J. Am. Chem. Soc. 2001, 123, 526-533.

33. Gieselman, M. D.; Xie, L.; van der Donk, W. A. Org. Lett. 2001, 3, 1331-1334.

34. Hondal, R. J.; Nilsson, B. L.; Raines, R. T. J. Am. Chem. Soc. 2001, 123, 5140-5141.

35. Quaderer, R.; Sewing, A.; Hilvert, D. Helv. Chim. Acta 2001, 84, 1197-1206.

36. Quaderer, R.; Hilvert, D. Chem. Commun. 2002, 2620-2621.

37. Metanis, N.; Keinan, E.; Dawson, P. E. Angew. Chem. Int. Ed. 2010, 49, 7049-7053.

38. Mitchell, N. J.; Malins, L. R.; Liu, X.; Thompson, R. E.; Chan, B.; Radom, L.; Payne, R. J. J. Am. Chem. Soc. 2015, 137, 14011-14014.

39. Reddy, P. S.; Dery, S.; Metanis, N. Angew. Chem. Int. Ed. 2016, 55, 992-995.

40. Mousa, R.; Reddy, P. S.; Metanis, N. Synlett 2017, 28, 1389-1393.

41. Mousa, R.; Notis Dardashti, R.; Metanis, N. Angew. Chem. Int. Ed. 2017, 56, 15818-15827.

42. Dawson, P. E. Isr. J. Chem. 2011, 51, 862-867.

43. Malins, L. R.; Mitchell, N. J.; McGowan, S.; Payne, R. J. Angew. Chem. Int. Ed. 2015, 54, 12716-12721.

44. Dery, S.; Reddy, P. S.; Dery, L.; Mousa, R.; Dardashti, R. N.; Metanis, N. Chem. Sci. 2015, 6, 6207-6212.

45. Dery, L.; Reddy, P. S.; Dery, S.; Mousa, R.; Ktorza, O.; Talhami, A.; Metanis, N. Chem. Sci. 2017, 8, $1922-1926$.

46. Mitchell, N. J.; Sayers, J.; Kulkarni, S. S.; Clayton, D.; Goldys, A. M.; Ripoll-Rozada, J.; Barbosa Pereira, P. J.; Chan, B.; Radom, L.; Payne, R. J. Chem 2017, 2, 703-715.

47. Mitchell, N. J.; Kulkarni, S. S.; Malins, L. R.; Wang, S.; Payne, R. J. Chem. Eur. J. 2017, 23, 946-952.

48. Shimodaira, S.; Takei, T.; Hojo, H.; Iwaoka, M. Chem. Commun. 2018, 54, 11737-11740.

49. Flemer, S.; Hondal, R. J. Biopolymers 2011, 96, 439-439.

50. Schroll, A. L.; Hondal, R. J.; Flemer, S. J Pept Sci 2012, 18, 155-162.

51. Ste. Marie, E. J.; Ruggles, E. L.; Hondal, R. J. J. Pept. Sci. 2016, 22, 571-576.

52. Giustarini, D.; Dalle-Donne, I.; Colombo, R.; Milzani, A.; Rossi, R. Nitric Oxide 2008, 19, 252-258.

53. Whedon, S. D.; Markandeya, N.; Rana, A. S.; Weller, C. E.; Senger, N. A.; Turecek, F.; Strieter, E. R.; Chatterjee, C. J. Am. Chem. Soc. 2016, 138, 13774-13777.

54. Cordeau, E.; Cantel, S.; Gagne, D.; Lebrun, A.; Martinez, J.; Subra, G.; Enjalbal, C. Org. Biomol. Chem. 2016, 14, 8101-8108.

55. Zhao, Z.; Metanis, N. Angew. Chem. Int. Ed. 2019, doi: 10.1002/ange.201909484.

56. Bang, D.; Kent, S. B. H. Angew. Chem. Int. Ed. 2004, 43, 2534-2538.

57. Johnson, E. C. B.; Malito, E.; Shen, Y.; Rich, D.; Tang, W.-J.; Kent, S. B. H. J. Am. Chem. Soc. 2007, 129, 11480-11490.

58. Piontek, C.; Varón Silva, D.; Heinlein, C.; Pöhner, C.; Mezzato, S.; Ring, P.; Martin, A.; Schmid, F. X.; Unverzagt, C. Angew. Chem. Int. Ed. 2009, 48, 1941-1945.

59. Seenaiah, M.; Jbara, M.; Mali, S. M.; Brik, A. Angew. Chem. Int. Ed. 2015, 54, 12374-12378.

60. Johnson, E. C. B.; Kent, S. B. H. J. Am. Chem. Soc. 2006, 128, 6640-6646.

61. Blanco-Canosa, J. B.; Dawson, P. E. Angew. Chem. Int. Ed. 2008, 47, 6851-6855.

62. Blanco-Canosa, J. B.; Nardone, B.; Albericio, F.; Dawson, P. E. J. Am. Chem. Soc. 2015, 137, 7197-7209. 
63. Moyal, T.; Hemantha, H. P.; Siman, P.; Refua, M.; Brik, A. Chem. Sci. 2013, 4, 2496-2501.

64. Hackeng, T. M.; Griffin, J. H.; Dawson, P. E. Proc. Natl. Acad. Sci. USA 1999, 96, 10068-10073.

65. Ireland, D. C.; Clark, R. J.; Daly, N. L.; Craik, D. J. J. Nat. Prod. 2010, 73, 1610-1622.

66. Claeson, P.; Göransson, U.; Johansson, S.; Luijendijk, T.; Bohlin, L. J. Nat. Prod. 1998, 61, 77-81.

67. Jennings, C.; West, J.; Waine, C.; Craik, D.; Anderson, M. Proc. Natl. Acad. Sci. USA 2001, 98, 10614-10619.

68. Saether, O.; Craik, D. J.; Campbell, I. D.; Sletten, K.; Juul, J.; Norman, D. G. Biochemistry 1995, 34, 4147-4158.

69. Niyomploy, P.; Chan, L. Y.; Poth, A. G.; Colgrave, M. L.; Sangvanich, P.; Craik, D. J. Pept. Sci. 2016, 106, $796-805$.

70. Tang, S.; Zuo, C.; Huang, D. L.; Cai, X. Y.; Zhang, L. H.; Tian, C. L.; Zheng, J. S.; Liu, L. Nat. Protoc. 2017, 12, 2554-2569.

71. Flood, D. T.; Hintzen, J. C. J.; Bird, M. J.; Cistrone, P. A.; Chen, J. S.; Dawson, P. E. Angew. Chem. Int. Ed. 2018, 57, 11634-11639.

72. Daly, N. L.; Love, S.; Alewood, P. F.; Craik, D. J. Biochemistry 1999, 38, 10606-10614. 